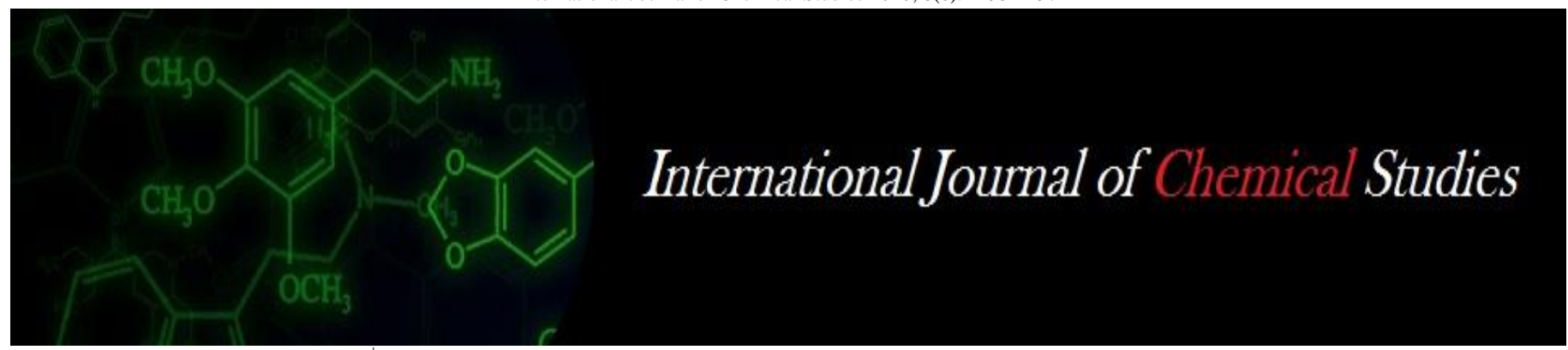

P-ISSN: 2349-8528

E-ISSN: 2321-4902

www.chemijournal.com

IJCS 2020; 8(6): 2295-2297

(C) 2020 IJCS

Received: 12-09-2020

Accepted: 16-11-2020

Chilukuri Navya Sree

Department of Agronomy, Sam

Higginbottom University of

Agriculture, Technology and

Sciences, Prayagraj,

Uttar Pradesh, India

Umesha C

Department of Agronomy, Sam

Higginbottom University of

Agriculture, Technology and

Sciences, Prayagraj,

Uttar Pradesh, India

\section{Marri Prasanthi}

Department of Agronomy, Sam

Higginbottom University of

Agriculture, Technology and

Sciences, Prayagraj,

Uttar Pradesh, India

Battula Sai Kumar Reddy

Department of Agronomy, Sam

Higginbottom University of

Agriculture, Technology and

Sciences, Prayagraj,

Uttar Pradesh, India

\section{Effect of phosphorus and iron levels on growth and economics of Chickpea (Cicer arietinum $\mathrm{L}$.)}

\author{
Chilukuri Navya Sree, Umesha C, Marri Prasanthi and Battula Sai \\ Kumar Reddy
}

DOI: https://doi.org/10.22271/chemi.2020.v8.i6ag.11117

\begin{abstract}
The investigation was carried out to study in rabi 2019 to study the effect of Phosphorus and Iron on growth and yield of chickpea (Cicer arietinum L.). The experiment consists of nine treatments replicated thrice laid out in Randomized Block Design. The treatment consisted of micronutrients viz. Phosphorus at $20 \mathrm{~kg} / \mathrm{ha}, 40 \mathrm{~kg} / \mathrm{ha}$ and $60 \mathrm{~kg} / \mathrm{ha}$ and Iron $2 \mathrm{~kg} / \mathrm{ha}, 4 \mathrm{~kg} / \mathrm{ha}$ and $6 \mathrm{~kg} / \mathrm{ha}$ whose effect is observed on Chickpea. Among the treatments it was observed that the treatment with application of $60 \mathrm{~kg} / \mathrm{ha}$ Phosphorus $+6 \mathrm{~kg} / \mathrm{ha}$ Iron was found to be the best treatment for obtaining growth and economics. Growth parameters such as plant height $(70.71 \mathrm{~cm})$, plant dry matter $(24.49 \mathrm{~g} / \mathrm{plant})$ found to be maximum in treatment combination $60 \mathrm{~kg} / \mathrm{ha}$ Phosphorus $+6 \mathrm{~kg} / \mathrm{ha}$ Iron, crop growth rate $(13.53$ $\mathrm{g} / \mathrm{m} 2 /$ day $)$ and relative growth rate $(0.021 \mathrm{~g} / \mathrm{g} /$ day $)$ found to be maximum in treatment combination 40 $\mathrm{kg} / \mathrm{ha}$ Phosphorus $+2 \mathrm{~kg} / \mathrm{ha}$ Iron. Economics viz., gross return (INR 128836.20/ha), net return (INR 82071.20), B:C ratio (1.75), was also recorded higher with the application of $60 \mathrm{~kg} / \mathrm{ha}$ Phosphorus +6 $\mathrm{kg} / \mathrm{ha}$ Iron. Therefore, application of $60 \mathrm{~kg} / \mathrm{ha}$ Phosphorus $+6 \mathrm{~kg} / \mathrm{ha}$ Iron was more productive and economically feasible.
\end{abstract}

Keywords: Phosphorus, iron, chickpea, growth, yield and B:C ratio

\section{Introduction}

Chickpea (Cicer arietinum L.), the premier pulse crop of India, popularly known as Gram or Bengal gram is mainly grown in Rabi season. It is the member of the family Leguminaceae and sub family Papilionaceae. Phosphorus is known to play beneficial role in legume growth by promoting extensive root development and nodulation (Sarawgi et al., 1999) ${ }^{[7]}$. Phosphorus application to legumes plays a key role in the formation of energy rich phosphate bonds, phospholipids and for development of root system (Tisdale et al. 1999). Iron plays a crucial role in redox system in cell and various enzymes. Dicotyledonous and grami-neaceous plants have different strategies to acquire Iron (Marschner, 2012) ${ }^{[6]}$. The growth and yield data indicates that the application of Fe singly or in combination with other element in various groups increased pod bearing, branching, test weight, total dry weight, pods and yield of chickpea. Keeping the above facts in view the present investigation was undertaken to study the effect of Phosphorus and Iron levels of growth and yield of chickpea (Cicer arietinum L.) during rabi 2019.

\section{Materials and Methods}

For the intended study, nine treatments were tested under three replications and laid out in randomized block design. Phosphorus viz. $20 \mathrm{~kg} / \mathrm{ha}, 40 \mathrm{~kg} / \mathrm{ha}$ and $60 \mathrm{~kg} / \mathrm{ha}$ and Iron $2 \mathrm{~kg} / \mathrm{ha}, 4$ $\mathrm{kg} / \mathrm{ha}$ and $6 \mathrm{~kg} / \mathrm{ha}$. The soil of the experimental field was sandy loam in texture, slightly alkaline reaction ( $\mathrm{pH} 7.5)$ with low level of organic carbon $(0.34 \%)$, available $\mathrm{P}(19.5 \mathrm{~kg} / \mathrm{ha})$ and higher level of $\mathrm{K}(92 \mathrm{~kg} / \mathrm{ha})$. At initial stage select random five plants from net plot area for further recording observations at 20 days sequence. The crop management practices were similar in all treatments but there is a difference in fertilizer application to each treatment. Application of Phosphorus and Iron were applied as basal application at the time of sowing as per treatments. The treatment combinations are T 1 - Phosphorus $20 \mathrm{~kg} / \mathrm{ha}+\operatorname{Iron} 2 \mathrm{~kg} / \mathrm{ha}$, T 2Phosphorus $20 \mathrm{~kg} / \mathrm{ha}$ + Iron $4 \mathrm{~kg} / \mathrm{ha}$, T 3- Phosphorus $20 \mathrm{~kg} / \mathrm{ha}$ + Iron $6 \mathrm{~kg} / \mathrm{ha}$, T 4Phosphorus 40 kg/ha + Iron $2 \mathrm{~kg} / \mathrm{ha}$, T 5- Phosphorus $40 \mathrm{~kg} / \mathrm{ha}+$ Iron 4
Corresponding Author: Chilukuri Navya Sree Department of Agronomy, Sam Higginbottom University of Agriculture, Technology and Sciences, Prayagraj, Uttar Pradesh, India 
kg/ha, T 6- Phosphorus $40 \mathrm{~kg} / \mathrm{ha}+$ Iron $6 \mathrm{~kg} / \mathrm{ha}$, T7Phosphorus $60 \mathrm{~kg} / \mathrm{ha}+$ Iron $2 \mathrm{~kg} / \mathrm{ha}, \mathrm{T}$ 8- Phosphorus 60 $\mathrm{kg} / \mathrm{ha}+$ Iron $4 \mathrm{~kg} / \mathrm{ha}$, T 9- Phosphorus $60 \mathrm{~kg} / \mathrm{ha}+$ Iron 6 $\mathrm{kg} / \mathrm{ha}$. Hand weeding was done after 25 \& 45 DAS. Two irrigations were given, one at pre-flowering and one at before pod formation stage. Nipping has done at about 30-40 days after sowing and it promotes the lateral branching, thus the plants become more vigorous and produce more flowers, pods and yield per plant increases. The observations were recorded on different growth parameters at 120 DAS viz. plant height $(\mathrm{cm})$, dry weight $(\mathrm{g})$, crop growth rate $(\mathrm{g} / \mathrm{m} 2 /$ day $)$, relative growth rate (g/g/day), Economics viz. gross return, net return, B:C ratio. Spacing maintained was $30 \times 10 \mathrm{~cm}$.

\section{Results and Discussion}

\section{A. Growth Parameters: Plant height $(\mathbf{c m})$}

The plant height at 120 DAS, significant and maximum $(70.71 \mathrm{~cm})$ was observed in treatment combination $60 \mathrm{~kg} / \mathrm{ha}$ Phosphorus $+6 \mathrm{~kg} / \mathrm{ha}$ Iron were recorded as compared to other treatments. However, on par with the treatment combination with $20 \mathrm{~kg} / \mathrm{ha}$ Phosphorus + $6 \mathrm{~kg} / \mathrm{ha}$ Iron $(69.35$ $\mathrm{cm})$. The plant height was increased with the application of Phosphorus, due to the fact that the phosphorus is a vital component structure of ATP during photosynthesis. Phosphorus plays a major role from the beginning of seedling growth throu+gh to the formation of maturity and grain. Thus, it is essential for the general growth and vigor of the plants. These results are consistent with that achieved from Dotaniya et al., (2013). The increase in the availability of Iron to plant might have stimulated the metabolic and enzymatic activities thereby increasing the growth of the crop Trivedi et al., (2011) ${ }^{[9]}$.

\section{Plant dry matter (g)}

At 120 DAS, Treatment with the application of $60 \mathrm{~kg} / \mathrm{ha}$ Phosphorus $+6 \mathrm{~kg} / \mathrm{ha}$ Iron was shown significantly maximum plant dry weight which is of (24.49 g), however treatments with combinations of $40 \mathrm{~kg} / \mathrm{ha}$ Phosphorus $+2 \mathrm{~kg} / \mathrm{ha}$ Iron (24.48 g), was on par with the treatment combination $60 \mathrm{~kg} / \mathrm{ha}$ Phosphorus $+6 \mathrm{~kg} / \mathrm{ha}$ Iron. The total dry matter production depends upon photosynthesis ability of a plant which in turn depends on the dry matter accumulation in leaves, dry matter accumulation per plant were significantly higher with increasing levels of Phosphorus in chickpea Arya et al., (2002) ${ }^{[2]}$. Increasing levels of Iron significantly increased the dry matter accumulation Kuldeep et al., (2018) ${ }^{[5]}$.

Crop growth rate $(\mathrm{g} / \mathrm{m} 2 / \mathrm{day})$

At 100-120 DAS, Treatment with the application of $40 \mathrm{~kg} / \mathrm{ha}$
Phosphorus $+2 \mathrm{~kg} / \mathrm{ha}$ Iron was shown significantly maximum crop growth rate which is of $(13.53 \mathrm{~g} / \mathrm{m} 2 /$ day $)$, however treatments with combinations of $20 \mathrm{~kg} / \mathrm{ha}$ Phosphorus +6 $\mathrm{kg} / \mathrm{ha}$ Iron $(11.35 \mathrm{~g} / \mathrm{m} 2 /$ day $)$ and $40 \mathrm{~kg} / \mathrm{ha}$ Phosphorus +6 $\mathrm{kg} / \mathrm{ha}$ Iron $(9.37 \mathrm{~g} / \mathrm{m} 2 /$ day $)$ was on par with the treatment combination $40 \mathrm{~kg} / \mathrm{ha}$ Phosphorus $+2 \mathrm{~kg} / \mathrm{ha}$ Iron. The increase in the availability of Iron might have stimulate the metabolic activity by enhancing the chlorophyll component in leaves which leads to accumulation plays a crucial role in crop growth rate. Alam and Haider (2006) ${ }^{[1]}$ and Kibe et al., (2006).

\section{Relative growth rate (g/g/day)}

At 100-120 DAS, Treatment combination with the application of $40 \mathrm{~kg} / \mathrm{ha}$ Phosphorus $+2 \mathrm{~kg} / \mathrm{ha}$ Iron was shown significantly maximum relative growth rate which is of $(0.021$ $\mathrm{g} / \mathrm{g} /$ day), however treatments with combinations of $20 \mathrm{~kg} / \mathrm{ha}$ Phosphorus $+6 \mathrm{~kg} / \mathrm{ha}$ Iron $(0.020 \mathrm{~g} / \mathrm{g} /$ day $)$ and $40 \mathrm{~kg} / \mathrm{ha}$ Phosphorus $+6 \mathrm{~kg} / \mathrm{ha}$ Iron $(0.016 \mathrm{~g} / \mathrm{g} / \mathrm{day})$ was on par with the treatment combination $40 \mathrm{~kg} / \mathrm{ha}$ Phosphorus $+2 \mathrm{~kg} / \mathrm{ha}$ Iron. These results are similar with Alam and Haider (2006) ${ }^{[1]}$ and Kibe et al., (2006).

\section{B. Economics \\ Cost of cultivation, Gross Return, Net Return and B: C Ratio}

The cost of cultivation of chickpea crop recorded numerically higher (Rs 45325/ha) value for the treatment of application of $60 \mathrm{~kg} / \mathrm{ha}$ Phosphorus $+6 \mathrm{~kg} / \mathrm{ha}$ Iron. Numerically minimum cost of cultivation was recorded with application of treatment combination of $20 \mathrm{~kg} / \mathrm{ha}$ Phosphorus $+2 \mathrm{~kg} / \mathrm{ha}$ Iron (Rs 41085/ha) in treatment.

Maximum gross return was recorded with application of 60 $\mathrm{kg} / \mathrm{ha}$ Phosphorus +6 kg/ha Iron (Rs.128836.20/ha) which was highest overall the treatments, minimum gross return was recorded with the application of $60 \mathrm{~kg} / \mathrm{ha}$ Phosphorus +4 $\mathrm{kg} / \mathrm{ha}$ Iron (Rs.124295.5/ha).

Numerically higher net return was recorded with application of $60 \mathrm{~kg} / \mathrm{ha}$ Phosphorus + $6 \mathrm{~kg} / \mathrm{ha}$ Iron (Rs.82071.20/ha) which was highest over all the treatments, minimum net return was recorded with application of treatment combination $20 \mathrm{~kg} / \mathrm{ha}$ Phosphorous $+2 \mathrm{~kg} / \mathrm{ha}$ Iron (Rs.66356.68/ha).

Highest Benefit Cost ratio was recorded with application of $60 \mathrm{~kg} / \mathrm{ha}$ Phosphorus + $6 \mathrm{~kg} / \mathrm{ha}$ Iron (1.75) which was superior over all the treatments however, the minimum B:C ratio was recorded with application of $40 \mathrm{~kg} / \mathrm{ha}$ Phosphorus + $6 \mathrm{~kg} / \mathrm{ha}$ Iron (1.51). These findings are similar with Devendra Singh and Harendra Singh (2012) ${ }^{[3]}$.

Table 1: Growth Attributes of chickpea as influenced by application of Phosphorus and Iron at harvest

\begin{tabular}{|c|c|c|c|c|}
\hline Treatments & $\begin{array}{l}\text { Plant height } \\
(\mathrm{cm})\end{array}$ & $\begin{array}{c}\text { Plant dry matter } \\
\text { (g/plant) }\end{array}$ & $\begin{array}{l}\text { Crop Growth Rate } \\
\text { (g/m2/day) }\end{array}$ & $\begin{array}{c}\text { Relative Growth Rate } \\
\text { (g/g/day) }\end{array}$ \\
\hline $\mathrm{T}_{1} 20 \mathrm{~kg} / \mathrm{ha}$ Phosphorus $+2 \mathrm{~kg} / \mathrm{ha}$ Iron & 67.67 & 18.99 & 6.377 & 0.011 \\
\hline $\mathrm{T}_{2} 20 \mathrm{~kg} / \mathrm{ha}$ Phosphorus $+4 \mathrm{~kg} / \mathrm{ha}$ Iron & 68.20 & 20.36 & 5.605 & 0.009 \\
\hline T3 $20 \mathrm{~kg} / \mathrm{ha}$ Phosphorus $+6 \mathrm{~kg} / \mathrm{ha}$ Iron & 69.35 & 19.84 & 11.355 & 0.020 \\
\hline $\mathrm{T}_{4} 40 \mathrm{~kg} / \mathrm{ha}$ Phosphorus $+2 \mathrm{~kg} / \mathrm{ha}$ Iron & 67.43 & 24.48 & 13.533 & 0.021 \\
\hline T5 $40 \mathrm{~kg} / \mathrm{ha}$ Phosphorus + 4 kg/ha Iron & 68.26 & 20.36 & 7.544 & 0.012 \\
\hline $\mathrm{T}_{6} 40 \mathrm{~kg} / \mathrm{ha}$ Phosphorus $+6 \mathrm{~kg} / \mathrm{ha}$ Iron & 68.35 & 20.62 & 9.372 & 0.016 \\
\hline $\mathrm{T}_{7} 60 \mathrm{~kg} / \mathrm{ha}$ Phosphorus $+2 \mathrm{~kg} / \mathrm{ha}$ Iron & 67.50 & 21.50 & 5.166 & 0.007 \\
\hline $\mathrm{T}_{8} 60 \mathrm{~kg} / \mathrm{ha}$ Phosphorus $+4 \mathrm{~kg} / \mathrm{ha}$ Iron & 66.50 & 20.51 & 6.750 & 0.011 \\
\hline $\mathrm{T}_{9} 60 \mathrm{~kg} / \mathrm{ha}$ Phosphorus $+6 \mathrm{~kg} / \mathrm{ha}$ Iron & 70.71 & 24.49 & 5.827 & 0.007 \\
\hline \multirow[t]{2}{*}{$\operatorname{S.Em}( \pm) \operatorname{CD}(\mathrm{p}=0.05)$} & 0.54 & 0.60 & 1.396 & 0.002 \\
\hline & 1.63 & 1.80 & 4.186 & 0.007 \\
\hline
\end{tabular}


Table 2: Economics of chickpea as influenced by application of Phosphorus and Iron.

\begin{tabular}{|c|c|c|c|c|}
\hline $\begin{array}{c}\text { Treatments } \\
\end{array}$ & Total cost of Cultivation (Rs/ha) & Gross return (Rs/ha) & Net return $(\mathrm{Rs} / \mathrm{ha})$ & B:C ratio \\
\hline $\mathrm{T}_{1} 20 \mathrm{~kg} / \mathrm{ha}$ Phosphorus $+2 \mathrm{~kg} / \mathrm{ha}$ Iron & 41085 & 107921.70 & 66356.68 & 1.60 \\
\hline $\mathrm{T}_{2} 20 \mathrm{~kg} / \mathrm{ha}$ Phosphorus $+4 \mathrm{~kg} / \mathrm{ha}$ Iron & 41205 & 108229.70 & 66064.68 & 1.57 \\
\hline $\mathrm{T}_{3} 20 \mathrm{~kg} / \mathrm{ha}$ Phosphorus $+6 \mathrm{~kg} / \mathrm{ha}$ Irons & 41325 & 109911.60 & 67146.61 & 1.57 \\
\hline $\mathrm{T}_{4} 40 \mathrm{~kg} / \mathrm{ha}$ Phosphorus $+2 \mathrm{~kg} / \mathrm{ha}$ Iron & 43085 & 110220.30 & 66655.27 & 1.53 \\
\hline $\mathrm{T}_{5} 40 \mathrm{~kg} / \mathrm{ha}$ Phosphorus $+4 \mathrm{~kg} / \mathrm{ha}$ Iron & 43205 & 115255.70 & 71090.70 & 1.61 \\
\hline $\mathrm{T}_{6} 40 \mathrm{~kg} / \mathrm{ha}$ Phosphorus $+6 \mathrm{~kg} / \mathrm{ha}$ Iron & 43325 & 112285.80 & 67520.80 & 1.51 \\
\hline $\mathrm{T}_{7} 60 \mathrm{~kg} / \mathrm{ha}$ Phosphorus $+2 \mathrm{~kg} / \mathrm{ha}$ Iron & 45085 & 121780.60 & 76215.56 & 1.67 \\
\hline $\mathrm{T}_{8} 60 \mathrm{~kg} / \mathrm{ha}$ Phosphorus $+4 \mathrm{~kg} / \mathrm{ha}$ Iron & 45205 & 118129.00 & 71964.03 & 1.56 \\
\hline $\mathrm{T}_{9} 60 \mathrm{~kg} / \mathrm{ha}$ Phosphorus + $6 \mathrm{~kg} / \mathrm{ha}$ Iron & 45325 & 128836.20 & 82071.20 & 1.75 \\
\hline
\end{tabular}

\section{Conclusion}

From the experimental findings, it can be concluded that for obtaining higher yield components with better quality of chickpea (Pusa 362) has fertilized with the application of Phosphorus $60 \mathrm{~kg} / \mathrm{ha}$ and Iron $6 \mathrm{~kg} / \mathrm{ha}$ was found more growth effective and as well as economic (Rs. 82071.20/ha) and maximum $\mathrm{B}: \mathrm{C}$ ratio recorded (1.75).

\section{References}

1. Alam MZ, Haider SA. Growth attributes of chickpea (Cicer arietinum L.) cultivars in relation to different doses of nitrogen fertilizer. Journal of Life and Earth sciences 2006;239:291-299.

2. Arya RL, Kushwaha BL, Singh BN. Effect of phosphorus management on growth, yield attributes and yield of maize- chickpea cropping system. Indian Journal of Pulse Research 2002;15:161-165.

3. Devendra Singh, Harendra Singh. Effect of Phosphorus and Zinc nutrition on yield, nutrient uptake and quality of chickpea (Cicer arietinum L.) Ann. Pl. Soil Res. 2012; 14(1):71-74.

4. Dotaniya ML et al. role of phosphorus in chickpea (Cicer arietinum L.) production 2014;9(51):3736-3743.

5. Kuldeep PD, Kumawat, Vipen Bhadu, Sumeriya HK, Vinod Kumar. Effect of Iron and Zinc Nutrition on Growth Attributes and Yield of Chickpea (Cicer arietinum L.). Int. J. Curr. Microbial. App. Sci 2018;7(08):2837-2841.

6. Marschner P. Marschner's mineral nutrition of higher plants, 3rd edn. Elsevier, Oxford 2012

7. Sarawgi SK, Tiwari PK, Tripathi RS. Uptake and balance sheet of nitrogen and phosphorus in gram (Cicer arietinum) as influenced by phosphorus, bio-fertilizer and micronutrients under rainfed condition. Indian Journal of Agronomy 1999;44(4):768-722.

8. Tisdale SL, Nelson WL, Beaton JD. "Soil Fertility and Fertilizers," 4th ed. Macmillan, New York 1985.

9. Trivedi AK, Hemantaranjan A, Pandey SK. Iron application may improve growth and yield of soyabean. Indian Journal of plant physiology 2011;16(34):309-313. 